Abstracta Iranica

Revue bibliographique pour le domaine irano-aryen

Volume 34-35-36 | 2017

Comptes rendus des publications de 2011-2013

\title{
Vijay Satee. The Lion-Bull Motifs of Persepolis: The Zoogeographic Context
}

\section{Rémy Boucharlat}

\section{(2) OpenEdition}

10 Journals

\section{Édition électronique}

URL : http://journals.openedition.org/abstractairanica/41785

DOI : 10.4000/abstractairanica.41785

ISSN : 1961-960X

Éditeur :

CNRS (UMR 7528 Mondes iraniens et indiens), Éditions de l'IFRI

Référence électronique

Rémy Boucharlat, «Vijay Satee. The Lion-Bull Motifs of Persepolis: The Zoogeographic Context », Abstracta Iranica [En ligne], Volume 34-35-36 | 2017, document 103, mis en ligne le 30 décembre 2016, consulté le 05 octobre 2020. URL : http://journals.openedition.org/abstractairanica/41785; DOI : https://doi.org/10.4000/abstractairanica.41785

Ce document a été généré automatiquement le 5 octobre 2020.

Tous droits réservés 


\title{
Vijay Satee. The Lion-Bull Motifs of Persepolis: The Zoogeographic Context
}

\author{
Rémy Boucharlat
}

\section{RÉFÉRENCE}

Vijay Satee. «The Lion-Bull Motifs of Persepolis: The Zoogeographic Context ». Iranian Journal of Archaeological Studies, 2, 1, 2012, p. 75-84.

1 Les sculpteurs de Persépolis ont du s'inspirer de modèles vivants pour représenter le lion sur les bas-reliefs, car cet animal est encore présent dans l'Iran antique pour ne disparaître définitivement qu'au milieu du $\mathrm{XX}^{\mathrm{e}} \mathrm{s}$. Le taureau pose un autre problème : sa représentation sur les chapiteaux des résidences royales est du type Bos taurus, la variété domestique, la sculpture dans les scènes de combat avec le lion est proche de l'espèce Bos primigenius. Or, si la présence de ce dernier est attestée par des ossements dans des sites archéologiques du $\mathrm{VII}^{\mathrm{e}}$ au IV ${ }^{\mathrm{e}}$ mill. av. J.-C., vivant, il n'est pas attesté plus tard, d'après les recherches actuelles. Sa représentation est cependant illustrée par d'autres supports contemporains, sceaux, rhytons, etc. On peut ajouter également la poterie peinte un peu antérieure. Une espèce sauvage devait encore exister.

\section{AUTEURS}

RÉMY BOUCHARLAT

CNRS, Lyon 